DOI https://doi.org/10.30525/978-9934-26-045-2-16

\title{
REGULATIONS FOR ELECTRONIC DOCUMENTS FLOW IN PUBLIC GOVERNANCE OF UKRAINE
}

\author{
Vasynova N. S. \\ Candidate of Pedagogic Sciences, \\ Associate Professor at the Public Service and Educational and Social \\ Institutions Management Department \\ Luhansk Taras Shevchenko National University \\ Starobilsk, Luhansk region, Ukraine
}

Modern means of documents management in Ukrainian public governance is an integral part of domestic informational processes, which indeed effect the digital development of the country. That is why, substantive examination of all introduction components of effective electronic document flow implementation and legal framework analysis, which provides implementation of automation steps of documentation management at institutions, is a significant step for digitalization process acceleration.

Various aspects of electronic documents flow regulatory support, peculiarities and problems of electronic documents flow implementation and functioning at local executive authorities, advantages and perspectives of EDFS introduction to state bodies operation were reflected in works of: M. Velychkevych, N. Mitrofan, N. Kunanets [2], K. Kopnyak, V. Pokynchereda [4], A. Maystrenko [5], L. Melnychuk, M. Holovchenko [6] etc.

As is argued by the researchers, we fail to keep pace with Western European Countries for five years approximately related to introduction of electronic documents flow systems [2], in USA and EC electronic documents flow has being used for more than ten years already. However, based on the results of previous researches [1], it is still too early to speak of success and fails of Ukraine in this area, as we are at initial stage of this process. Taking into account general tendencies, consider main laws and regulations of Ukraine related to the problems of electronic documents flow, that is the aim of this article.

Legal and regulatory framework for documents management in Ukraine is based on the Constitution of Ukraine, and consists of regulations. We shall consider the following documents, regulating major organizational and legal framework of electronic documents flow and usage of electronic documents in Ukraine, within this research. 
Legal and regulatory base analysis of $[5 ; 8 ; 9]$, provides with possibility to divide them conditionally into three groups:

1) general, regulating the information society development;

2) documents related to electronic document flow and archival storage of electronic documents;

3) documents addressed to electronic governance

Thereat, it is possible to note that electronic documents flow was stated legislatively in the country in 2003. The Ukrainian Law «On Electronic Documents and Electronic Documents Flow» dated 22.05.2003 No. 851-IV is a main document, regulating operations within this field.

On November 7, 2018, the Ukrainian Law «On Authorized Electronic Services» entered into force. Since this date, the Ukrainian Law «On Electronic Digital Signature» has terminated. One of important innovations of the law on Authorized Electronic Services is that it introduces the notion «authorized electronic signature», substituting the notion «electronic digital signature» [10].

In accordance with the Law (Art. 1 of Law No. 45), Authorized electronic signature (AES) is an improved electronic signature, created through authorized electronic signature mean, and is based on the authorized certificate of public key.

The Law «On Accountancy and Financial Statements» is the next regulation, related to the primary documents directly. This Law determines legal frameworks for regulation, organization, maintenance of accountancy and financial statements drawing up in Ukraine [8].

Therefore, as a rule, documentation of management information at state institutions is electronic, applying authorized electronic signature, authorized electronic seal and authorized electronic time marking out, except of the cases of reasonable grounds presence for documentation of management information in hard copies, with which some issues are acknowledged [9]:

- documents, containing information with limited access, the claim related to protection of which is provided by the law;

- electronic documents that cannot be used as original ones in accordance with the law;

- the documents, the claim for processing of which in hard copies is provided by the resolutions of the Cabinet of Ministers of Ukraine.

Electronic documents certified with AES shall be in full force and effect, as if been hand-signed and sealed. The process of these signatures issuance and usage us regulated by Ukrainian Law «On Authorized Electronic Services» and controlled by the Ministry of Justice of Ukraine. 
The main advantages of authorized electronic signature may include the following: cuts in expenditures for paper documents maintenance, removal of routine processes, slowing down quick renewal of documents within institutions. Therefore, the best option for rearrangement of internal processes of institution documentation support is possible providing introduction of electronic documents flow, which is one of main instruments of increase of documentation digitalization level and provision of full document flow within state bodies.

The research has revealed that three laws regulate Ukrainian electronic documents flow: «On Electronic Documents and Electronic Documents Flow», «On Authorized Electronic Services» and «Law on Accountancy and Financial Statements». In accordance with these laws, electronic documents shall have the same legal force as their equivalents in hard copies. It was found out, that all key notions of electronic documents flow system were introduced to legal framework (authorized electronic signature, authorized electronic seal, electronic document, electronic notice, electronic documents flow system, electronic documents flow etc.).

It is also good that regulations on electronic documentation of management information and organization of work with electronic documents, electronic interdepartmental share are amended on regular basis that makes them up-to-date.

On course to digitalization of public administering and business structures, it is necessary to take into account the appropriate foreign experience related to the development of electronic documents flow systems for our country that is assigned to prospects of further researches in this area.

\section{References:}

1. Vasynyova N.S. Automation of document circulation as one of the components of the process of digitalization of public administration in Ukraine. Public administration and customs administration. 2020. № 4(27). URL: http://customs-admin.umsf.in.ua/archive/2020/4/9.pdf (access date: 20.02.2021). DOI: https://doi.org/10.32836/2310-9653-2020-4.7

2. Velychkevych M., Mitrofan N., Kunanets N. Electronic document management, trends and prospects. Lviv, 2010. S. $44-53$.

3. Some questions of documenting management activities URL: https://zakon.rada.gov.ua/laws/show/55-2018-\%D0\%BF\#Text (access date: 03.03.2021).

4. Kopnyak K. V., Pokinchereda V. V. Electronic document management in public administration: problems of implementation, advantages and prospects. Public administration: improvement and development. 
2020. № 10. URL: http://www.dy.nayka.com.ua/?op=1\&z=1798 (access date: 20.02.2021). DOI: 10.32702 / 2307-2156-2020.10.35

5. Maistrenko A. A. Normative and legal support of electronic document management in Ukraine: information-analytical review // Archives of Ukraine. 2016. № 3-4. Pp. 58-82.

6. Melnychuk L. I., Golovchenko M. M. Questions of introduction of electronic document circulation in public authorities. 2019. Volume 30 (69). № 1 Part 2. URL: http://efm.vsau.org/ (access date: 02.03.2021).

7. Regulatory framework. Modern trends in electronic document management. URL: https://sites.google.com/site/elektrdokumentoobig/normativno-pravova-baza (access date: 20.02.2021).

8. On accounting and financial reporting in Ukraine: Law of Ukraine of 14.11.2020, № 776-IX. URL: https://zakon.rada.gov.ua/laws/show/ 996-14\#Tex (access date: 02.03.2021).

9. On electronic trust services: Law of Ukraine dated 05.10.2017 № 2155-VIII. URL: https://zakon.rada.gov.ua/laws/show/2155-19\#Text (access date: 02.03.2021).

10. Legal force of EDI and legislation of Ukraine. URL: https://edin.ua/yuridichna-sila-edo-ta-zakonodavstvo-ukra\%D1\%97ni/ (access date: 02.03.2021).

DOI https://doi.org/10.30525/978-9934-26-045-2-17

\title{
СУЧАСНІ МЕХАНІЗМИ ПЛАНУВАННЯ ІНТЕГРОВАНОГО РОЗВИТКУ ГРОМАД В УКРАЇНІ
}

\author{
Вяхірев М. О. \\ аспірант кафедри регіонального управління, \\ місиевого самоврядування та управління містом \\ Начіональної академії державного управління \\ при Президентові Украӥни \\ м. Київ, Україна, \\ заступник Обухівського міського голови \\ Обухівської міської ради \\ м. Обухів, Київська область, Украӥна
}

На сучасному етапі державотворення демократизація публічного управління та адміністрування, передача органам місцевого самоврядування значних повноважень для вирішення питань 